\title{
Simulation of the joint processing of pyrrhotite concentrate and nickeliferous oxidized ore
}

\author{
(C) Alexander M. Klyushnikov, ${ }^{+}$and Evgeny N. Selivanov* \\ Laboratory of Non-Ferrous Metals Pyrometallurgy. Institute of Metallurgy of Ural Branch of Russian \\ Academy of Sciences. Amundsen St., 101. Yekaterinburg, 620016. Russia. \\ Phone:+7 (343)382-21-18.E-mail:amk8@mail.ru
}

*Supervising author; ${ }^{+}$Corresponding author

Keywords: ore, concentrate, nickel, copper, cobalt, roasting, smelting, matte, slag, extraction.

Abstract
In this paper the issues of improving the efficiency of processing of pyrrhotite concentrates and magnesiasilicate nickeliferous ores are reviewed. An original technology is proposed, its basic stages are partial oxidative roasting of the concentrate and joint contractile melting the calcine with nickel ores to gain matte. Roasting of the pyrrhotite concentrate allows to extract $70-80 \%$ of sulfur from the concentrate into gases riched with $\mathrm{SO}_{2}$, reduce desulfurization during melting and extract nickel, copper, cobalt and precious metals from both raw materials into the matte. The implementation of fluxing potential of nickel ore completely eliminates the use of fluxes during smelting and increases the specific productivity of metallurgical units in concern of raw materials.

On the laboratory scale, the modeling of the main technological operations is performed to justify the technology. The possibility of separation of slag and matte with joint reagent-free melting $\left(1400^{\circ} \mathrm{C}\right)$ of the product of partial oxidative roasting and oxidized nickel ore, taken in equal quantities, is theoretically justified and experimentally confirmed. Parameters of the roasting of the pyrrhotite concentrate: temperature $800^{\circ} \mathrm{C}$, desulfurization degree $71.7 \%$. Pyrrhotite concentrate contained (\%wt.) $1.9 \mathrm{Ni}, 0.2 \mathrm{Cu}$, and $0.06 \mathrm{Co}$. Oxidized nickel ore contained (\%wt.) $1.2 \mathrm{Ni}$, and $0.06 \mathrm{Co}$. The slag basicity module (about 1) provides relatively low content of non-ferrous metals in the slag (\%wt.): $0.24 \mathrm{Ni}, 0.08 \mathrm{Co}$, and $0.04 \mathrm{Cu}$. Matte contained (\%wt.) 8.9 $\mathrm{Ni}, 0.22 \mathrm{Co}, 0.5 \mathrm{Cu}, 58.7 \mathrm{Fe}, 25.0 \mathrm{~S}$, and $6.6 \mathrm{O}$. Extraction level in the matte was $87.8 \%$ nickel, $48.0 \%$ cobalt, and $73.3 \%$ copper from their content in the initial mixture. High levels of matte enrichment degree with respect to the charge were achieved; their values were 5.5 for nickel, 5.7 for cobalt, and 4.5 for copper. Desulfurization degree during melting and metallization degree of matte were close to zero. The matte was suitable for processing with known routes.

The results are expected to be used in the development of technologies aimed to resumption of processing of oxidized nickeliferous ores from the Ural deposits.

\section{References}

[1] L.I. Leontiev, and E.N. Selivanov. State and directions of technology development in order to create environmentally friendly production of non-ferrous metallurgy. Proceedings of the congress "Fundamental research and applied development of processes of treatment and utilization of technogenic formations". Yekaterinburg: Institute of Metallurgy of Ural branch of Russian Academy of Sciences. 2017. P.70-74. (russian)

[2] S.M. Kozhakhmetov, S.A. Kvyatkovsky, M.K. Sultanov, Z.K. Tulegenova, and A.S. Semenova. Processing of oxidized copper ores and sulfide copper concentrates of Aktogay Deposit by pyrometallurgical methods. Complex use of mineral raw materials. 2018. No.3. P.54-62. (russian).

[3] E.N. Selivanov, A.M. Klyushnikov, and R.I. Gulyaeva. Use of quartz-containing materials as fluxes in copper smelting production. Metallurgist. 2017. Vol.61. No.1-2. P.155-161. DOI: 10.1007/s11015-0170469-x

[4] A.M. Klyushnikov, and E.N. Selivanov. Thermodynamic modeling of the joint processing of oxidized nickel ores and sulfide copper-bearing ores. Butlerov Communications. 2017. Vol.49. No.1. P.34-42. DOI: $10.37952 / R O I-j b c-01 / 17-49-1-34$

[5] E.N. Selivanov, R.I. Gulyaeva, and A.M. Klyushnikov. Investigation of structure and phase composition of copper-cobalt sulfide ore from Dergamyshskoye deposit. Nonferrous metals. 2016. No.3(879). P.1317. (russian) 
SIMULATION OF THE JOINT PROCESSING OF PYRRHOTITE CONCENTRATE AND NICKELIFEROUS... $110-117$

[6] E.N. Selivanov, A.M. Klyushnikov, V.M. Chumarev, R.I. Gulyaeva, and V.G. Lobanov. Composition and structure of products of the joint smelting of oxidized nickel ores and sulfide copper ores. Butlerov Communications. 2016. Vol.47. No.7. P.36-42. DOI: 10.37952/ROI-jbc-01/16-47-7-36

[7] Pat. 2657267 Russian Federation. The charge for reductive-and-sulfiding smelting of oxidized nickel ores. E.N. Selivanov, A.M. Klyushnikov, V.M. Chumarev, and R.I. Gulyaeva; applicant Institute of Metallurgy of Ural branch of Russian Academy of Sciences. No.2017120242; announced 08.06.2017; published 09.06.2018. Bul. No.16. (russian)

[8] A.M. Klyushnikov, E.N. Selivanov, R.I. Gulyaeva, and V.M. Chumarev. Joint pyrometallurgical processing of oxidized nickel ores and copper sulfide ores. Proceedings of the congress "Fundamental research and applied development of processes of treatment and utilization of technogenic formations". Yekaterinburg: Institute of Metallurgy of Ural branch of Russian Academy of Sciences. 2017. P.263-266. (russian)

[9] E.N. Selivanov, D.A. Tolocknov, and V.M. Chumarev. Prospects of the melting of oxide and sulfide ores to gain a copper-nickel matte. Nonferrous metallurgy. 2011. No.11. P.41-43. (russian)

[10] I.D. Reznik, G.P. Ermakov, and Ya.M. Shneerson. Nickel. Vol.2. Moscow: Science and Technology. 2001. 468p. (russian)

[11] I.D. Reznik, G.P. Ermakov, and Ya.M. Shneerson. Cobalt. Vol.1. Moscow: Machine Engineering. 1995. 440p. (russian)

[12] I.D. Reznik, G.P. Ermakov, and Ya.M. Shneerson. Nickel. Vol.3. Moscow: Science and Technology. 2003. 608p. (russian)

[13] F.K. Crundwell et al. Extractive metallurgy of nickel, cobalt and platinum-group metals. Oxford: Elsevier. 2011. 610p.

[14] N.V. Gudima et al. Technological calculations in the metallurgy of nonferrous metals: textbook. Moscow: Metallurgy. 1977. 255p. (russian)

[15] E.I. Yeliseev, A.I. Volkhin, G.G. Mikhailov, and B.N. Smirnov. Calculations of metallurgical processes of copper production: textbook. Chelyabinsk: Publishing center of South Ural State University. 2012. 221p. (russian)

[16] B.P. Blednov, V.E. Dulneva. Calculations on metallurgy of copper and nickel: textbook. Krasnoyarsk: State University of Non-ferrous Metals and Gold. 2004. 120p. (russian)

[17] A.G. Khoroshavin. Forsterite $2 \mathrm{MgO} \cdot \mathrm{SiO}_{2}$. Moscow: Heat Engineer. 2004. 368p. (russian)

[18] J.F. Elliott. Phase relationships in the pyrometallurgy of copper. Metallurgical and Materials Transactions B. 1976. Vol.7. Iss.1. P.17-33. DOI: 10.1007/BF02652816

[19] Information and technical guide to the best available technologies 12-2016. Production of nickel and cobalt. Moscow: Bureau of the best available technologies. 2016. 194p. (russian)

[20] Atlas of slags: reference book: transl. from german. Moscow: Metallurgy. 1985. 208p. (russian)

[21] S.S. Naboychenko, L.N. Ni, Ya.M. Shneerson, and L.V. Chugaev. Autoclave hydrometallurgy of nonferrous metals. Yekaterinburg: USTU-UPI. 2002. 940p. 